\title{
СТАН ПРОБЛЕМИ ФОРМУВАННЯ ПРОФЕСІЙНОГО ІМІДЖУ МАЙБУТНІХ УЧИТЕЛІВ ІНОЗЕМНИХ МОВ В ОСВІТНІЙ ПРАКТИЦІ
}

\author{
(C) Ткаченко Н.M., 2020 \\ https://orcid.org/0000-0003-1879-9159 \\ http://doi.org/10.34142/2312-2471.2020.63.18
}

У статті здійснено аналіз стану проблеми формування професійного іміджу вчителів іноземних мов в освітній практиці. Підкреслено, щзо наразі триває робота над розробленням стандартів вищої освіти з галузі знань 01 Освіта/Педагогіка, тому перелік компетентностей, якими має характеризуватися випускник ОП за предметною спеціальністю 014.02 Середня освіта (Мова $і$ література (з вказанням мови)) досі відсутній. Кваліфікація випускника изієі предметної спеціальності відповідає иостому рівню Національної рамки кваліфікацій. За результатами вивчення освітньопрофесійних програм підготовки фахівизів за спеціальністю 14.02 Середня освіта. Мова та література (із зазначенням мови) окреслено виявлені загальні тендениії. Серед них: відсутність чіткого завдання формування професійного іміджу майбутніх учителів іноземних мов у проиесі їх підготовки у ЗВО; зорієнтованість ОПП на розвиток фахових компетентностей майбутніх фахівців та відсутність належної уваги розвитку особистості майбутнього педагога, у якого професійні знання та вміння поєднувалися б із затребуваними в професї особистісними характеристиками, розвиненим емочійним інтелектом і стресостійкістю, спрямованістю на ділову самопрезентацію, зовнішню привабливість і хороші манери; наявність компетентностей, ио хоч i віддалено, але орієнтують підготовку майбутніх учителів іноземних мов на створення професійного іміджу. Репрезентовано результати самооиінювання науково-педагогічних працівників, які забезпечують освітній процес у ЗВО, щзодо їхньої готовності до реалізациї ідей іміджелогії у професійній діяльності та сформованості їх власного професійного іміджу. Отримані дані засвідчили фрагментарність знань респондентів про імідж як феномен, недостатнє володіння механізмами іміджетворення, наявність утруднень у формуванні власного професійного іміджу, щзо свідчить про недостатню готовність більшості науково-педагогічних працівників до іміджетворення.

Ключові слова: імідж, професійний імідж, майбутній учитель іноземних мов, професійна підготовка, заклад вищзої освіти.

Tkachenko N. M. The Problem State of Professional Image Forming for Future Foreign Language Teachers in Education Practice

The article analyzes the problem state of professional image forming for future foreign languages teachers in the educational process of higher educational 
establishments. It is emphasized that standards of higher education in the field of knowledge 01 Education / Pedagogy work are still to be developed. So, the list of competencies a graduate of the subject specialty 014.02 Secondary Education (Language and Literature (indicating the language)) should possess are still undefined. The qualification of a graduate of this subject specialty corresponds to the sixth level of the National Qualifications Framework. Based on the results of the study of educational and professional training programs in the specialty 14.02 Secondary education. Language and literature (indicating the language) the general trends were identified. Among them: the lack of clear task as for the future foreign language teachers' professional image forming in the process of their training in the higher educational establishment; focusing educational and professional training programs on the development of future professional competencies and the lack of proper attention to forming a future teacher's personality, whose professional knowledge and skills would be combined with the personal characteristics, developed emotional intelligence and stress resistance, and focusing on business selfpresentation, external attractiveness and good manners as well, which are of high demand in the profession; the presence of competencies that, although remotely, but direct the future foreign language teachers training on professional image forming. The scientific and pedagogical staff readiness for implementing the ideas of Imageology in their professional activities and the state of their professional image were clarified by means of self-assessment. The obtained data testified to the respondents' fragmentary knowledge about the image as a phenomenon and a mechanisms of image creating, difficulties in forming their own professional image, which indicates the insufficient level of most teaching staff readiness to image creating activities.

Key words: image, professional image, future foreign languages teacher, professional training, institution of higher education.

Постановка проблеми у загальному вигляді. Сучасна професійна освіта як основа економічного добробуту держави, важлива складова сталого розвитку суспільства, запорука професійної самореалізації та неперервного професійного розвитку особистості впродовж усього життя потребує педагога нового типу. В сучасній соціально-економічній ситуації дедалі загострюється конкуренція на ринку освітніх послуг.

Ринкова економіка актуалізує попит на конкурентоспроможних на європейському й світовому ринках праці, мобільних, комунікативно компетентних членів суспільства, яким притаманні лідерські якості, психологічна стійкість, професійні знання, адаптовані до ринкових умов, творча активність, впевненість у собі, здатність адаптуватися в умовах середовища, презентувати себе тощо. Значно розширились вимоги і до вчителя іноземних мов, виникли нові форми роботи, які він повинен опанувати, щоб задовольнити виклики сьогодення, підвищити власний соціальний успіх й забезпечити успішну презентацію себе як професіонала у педагогічному й інших середовищах.

3 огляду на це професійний імідж вчителя іноземних мов нового 
Збірник наукових праць «Педагогіка та психологія». - Харків, 2020. - Вип. 63.

покоління наразі стає затребуваною професійно-особистісною
характеристикою, необхідним атрибутом соціально-професійних взаємин i здійснює визначальний вплив на споживачів освітніх послуг.

Аналіз останніх досліджень і публікацій. В контексті означеної проблеми особливий інтерес представляють роботи, присвячені висвітленню теоретико-методологічних та методичних основ фахової підготовки вчителів іноземних мов (Безлюдна В., Бігич О., Задорожна I., Казачінер О., Князян М., Костікова I., Морська Л., Ніколаєва С., Тарнопольський О., Черниш В.); конструювання професійного іміджу працівників освітньої сфери (Бекетова О., Варданян М., Горовенко О., Дзязевич Ю., Довга Т., Ісаченко В., Калюжний А., Ковальова О., Ніколаєску I., Перелигіна О., Попова О., Розмолодчикова I., Тарасенко Н., Черепанова В. та ін.).

Виділення невирішених раніше частин загальної проблеми. Аналіз праць учених засвідчив наявність значних відмінностей у розумінні понять «імідж» та «професійний імідж», компонентного складу професійного іміджу педагога, а також у підходах до обгрунтування теоретичних і методологічних засад формування професійного іміджу вчителя, що пояснюється відсутністю на сьогоднішній день фундаментальної теорії іміджу.

Крім того, бракує системних психолого-педагогічних досліджень 3 проблеми формування професійного іміджу майбутніх учителів іноземних мов, що обмежує використання педагогічних факторів та забезпечення відповідних умов для його формування, гальмує розвиток іміджотворчої діяльності у педагогічних 3ВО, уповільнює застосування в освітньому процесі сучасних педагогічних технологій.

Розроблення концепції та педагогічної системи цілеспрямованого формування професійного іміджу майбутніх учителів іноземних мов у процесі професійної підготовки у ЗВО може стати орієнтиром для вищої педагогічної освіти у підготовці вчителів іноземних мов, конкурентних на ринку праці, здатних не лише здійснювати професійну діяльність на нових концептуальних засадах, втілювати державну політику розвитку особистості, задоволення ii освітніх і духовно-культурних потреб, а й презентувати себе як професіонала.

Формування цілей статті. Метою публікації $\epsilon$ з'ясування стану проблеми формування професійного іміджу вчителів іноземних мов в освітній практиці, що уможливить подальшу модернізацію усіх компонентів традиційної педагогічної системи 3 метою задоволення нових суспільних викликів.

Виклад основного матеріалу дослідження. На основі зіставлення підходів учених, власного теоретичного пошуку професійний імідж майбутнього вчителя іноземних мов визначено як статусно-рольову характеристику, що об'єднує систему зовнішніх (естетична вихованість, креативність), внутрішніх (індивідуальних (педагогічні здібності, рефлексивність) i професійних (гуманістичних, професійно-особистісних та ділових)) якостей i компетентностей фахівця (філологічна, методична, іміджотворча (володіння базовими технологіями та спеціальними техніками іміджотворчої діяльності, тактиками i стратегіями самопрезентації, 
самореалізації, самовираження)), що виявляється, підтверджується і розвивається в процесі оволодіння ним соціально-професійним досвідом, і покликана створити в громадськості образ соціально-професійної ролі, яку він конструює [1, с.60].

Принагідно зазначимо, що згідно 3 «Переліком галузей знань i спеціальностей, за якими здійснюється підготовка здобувачів вищої освіти» [9], кваліфікацію вчителя іноземних мов, починаючи з 2016 р., можуть здобувати студенти предметної спеціальності 014.02 Середня освіта (Мова і література (із зазначенням мови)) [10] спеціальності «014 Середня освіта (за предметними спеціальностями» галузі знань «01 Освіта/Педагогіка».

Варто також відмітити, що наразі триває робота над розробленням стандартів вищої освіти з галузі знань 01 Освіта/Педагогіка, тому перелік компетентностей, якими має характеризуватися випускник ОП за предметною спеціальністю 014.02 Середня освіта (Мова і література (з вказанням мови)) як стандартний модуль досі не оформився, і продовжує бути предметом наукових дискусій.

Відповідно до Національної рамки кваліфікацій випускник цієї предметної спеціальності за результатами навчання на бакалаврській програмі (шостий рівень НРК) має продемонструвати «концептуальні наукові та практичні знання, критичне осмислення теорій, ... інтерпретації та застосування даних спілкування з професійних питань, у тому числі іноземною мовою, усно та письмово» [8].

3 метою вивчення стану проблеми формування професійного іміджу майбутніх учителів іноземних мов в освітній практиці нами було проаналізовано освітньо-професійні програми підготовки фахівців за спеціальністю 14.02 Середня освіта. Мова та література (із зазначенням мови) першого (бакалаврського) рівня вищої освіти.

Об'єктом контекстного аналізу [2; 3; 4] стала інформація, розміщена у відкритому доступі на офіційних сайтах закладів вищої освіти, що здійснюють підготовку майбутніх учителів іноземних мов за першим (бакалаврським) рівнем вищої освіти щодо наявності окремих іміджевих компетентностей та відповідних програмних результатів навчання $[5 ; 6 ; 7]$. Окреслимо виявлені загальні тенденції.

Здійснений контент-аналіз, засвідчив, що завдання формування професійного іміджу майбутніх учителів іноземних мов у процесі їх підготовки у ЗВО цілеспрямовано не ставиться. Освітні програми підготовки майбутніх учителів іноземних мов переважно орієнтовані на розвиток фахових компетентностей майбутніх фахівців, при цьому не приділяється належна увага розвитку особистості майбутнього педагога, у якого професійні знання та вміння поєднувалися $\sigma$ із затребуваними в професії особистісними характеристиками: адекватною самооцінкою на базі сформованої Я-концепції; розвиненим емоційним інтелектом i, як наслідок, стресостійкістю; спрямованістю на ділову самопрезентацію, зовнішню привабливість і хороші манери.

Позитивною є тенденція до появи компетентностей, що хоч і віддалено, 
але орієнтують підготовку майбутніх учителів іноземних мов на створення професійного іміджу. Так у 23\% проаналізованих освітніх програм спостерігаємо такі компетентності, як «здатність до особистісного та професійного самовдосконалення, саморозвитку, самонавчання, саморегулювання, самоорганізації» або «здатність ефективно формувати комунікативну стратегію рідною та іноземною мовою, мати навички адаптації та роботи в команді», «здатність і готовність проявляти професійно-особистісні і психологічні якості, необхідні для здійснення своєї професійної діяльності, саморозвитку та самовдосконалення своєї педагогічної діяльності», «здатність навчатися протягом усього життя в контексті неперервної фахової підготовки й соціального життя, вдосконалювати й розвивати свій інтелектуальний i загальнокультурний рівень 3 високим рівнем самостійності».

Проте лише у 10\% освітніх програм формування окреслених компетентностей простежується в програмних результатах навчання. Недостатньо підкріпленими $€$ названі компетентності в частині переліку дисциплін навчального плану. Вони лише побіжно розкриваються у змісті окремих освітніх компонентів. У жодному ЗВО освітні програми підготовки майбутніх учителів іноземних мов за першим рівнем вищої освіти не містять окремих навчальних курсів, пов'язаних з іміджотворенням.

Отже, аналіз освітніх програм підготовки майбутніх учителів іноземних мов дозволив висновкувати, що зміст їхньої підготовки дуже повільно трансформується в напрямі задоволення потреб сьогодення щодо підготовки конкурентоспроможних фахівців, комунікативно компетентних, які характеризуються не тільки професійними знаннями, а й лідерськими якостями, психологічною стійкістю, творчою активністю, впевненістю у собі, здатністю адаптуватися в умовах середовища, презентувати себе тощо, про що засвідчує наявність таких компетентностей лише в окремих освітніх програмах.

3 огляду на це не можна констатувати наявність цілісної системи підготовки майбутніх фахівців до створення свого професійного іміджу, освітні програми яких було проаналізовано, що унеможливлює усвідомлення майбутніми вчителями іноземних мов своїх професійних можливостей, вироблення власного професійного стилю, визначення шляхів професійного зростання, a отже i не приносить бажаних результатів у сформованості професійного іміджу майбутніх фахівців.

Як відомо, якість підготовки майбутніх учителів іноземних мов, зокрема i рівень сформованості їх професійного іміджу залежить, перш за все, від готовності науково-педагогічних працівників, які безпосередньо забезпечують освітній процес у ЗВО, до реалізації ідей іміджелогії у власній професійній діяльності та сформованості їх власного професійного іміджу.

Із метою з'ясування стану речей нами було організовано розвідувальне дослідження, яким охоплено 114 науково-педагогічних працівників вишів, які здійснюють підготовку майбутніх учителів іноземних мов. Природно, досліджувані науково-педагогічні працівники володіли різним досвідом роботи. Щоб врахувати цю позицію та здійснити якісний аналіз результатів досліджень, респондентів було розподілено на умовні три групи: I група - викладачі зі 
стажем роботи більше 15 років (43 особи); II група - зі стажем від 5 до 15 років (36 осіб); III група - викладачі 3 педагогічним стажем до 5 років (35 осіб).

В ході інтерв'ювання, метою якого було виявлення рівня обізнаності респондентів про значення професійного іміджу для фахівця освітньої сфери 3 огляду на відповідність вимогам професійного стандарту та розуміння його функцій, науково-педагогічними працівниками було визнано необхідність формування професійного іміджу у майбутніх фахівців у сучасному світі та з'ясовано, що 73 особи (64\%) достатньо уваги приділяють власному професійному іміджу, зокрема його зовнішньому та внутрішньому складникам. 30 осіб $(26,3 \%)$ - не дуже серйозно ставляться до його підтримання в повсякденному житті, згадують про нього час від часу.

3 них 7 осіб $(6,1 \%)$ зазначили, що усвідомлюють значення іміджу для педагога, проте економічна ситуація, особливості соціальних відносин, зокрема, низький статус педагогічної професії, негативно вплинули на мотивацію щодо підтримання власного професійного іміджу. 11 осіб (9,6 \%) респондентів не замислювалися про значення професійного іміджу для педагога, не надавали йому особливого значення, оскільки на їх переконання, єдино важливим чинником успіху у професійній діяльності є бездоганне володіння фаховими знаннями та методиками. Зазначимо, що спостереження за респондентами дало підстави констатувати, що не всі викладачі були відвертими, освіченість та педагогічний такт сприяли їхньому вибору позитивного варіанта відповіді.

Далі у межах розвідувального дослідження нами було запропоновано всім учасникам оцінити власні компетентності та здатності (знання, уміння, інші характеристики особистості) щодо іміджотворчої діяльності за десятибальною шкалою, де 0 -уміння (якість, властивість) не сформована; 9 - характеризується високим рівнем сформованості. Опитування проводилося за умови дотримання анонімності, що уможливлювало більшу відвертість та об'єктивність у відповідях респондентів, хоча не гарантувало повну відповідність реальній ситуації.

Результати самооцінювання подано у табл. 1.

Як видно 3 табл. 1, найвища середня оцінка у групи викладачів зі стажем роботи від 5 до 15 років - 5,6. Проте і в інших групах середні оцінки суттєво не різняться і становлять 5,3 і 4,7 у I і III групах відповідно. Принагідно зазначимо, що такі досить низькі середні показники, на жаль, свідчать про певні труднощі, пов'язані із реалізацією іміджотворчої діяльності науково-педагогічними працівниками, що ймовірно позначається і на підготовці майбутніх фахівців до іміджотворення.

Таблиця 1

\section{РЕЗУЛЬТАТИ САМООЦНКИ ВИКЛАДАЧАМИ ЗДАТНОСТІ ДО ІМІДЖОТВОРЧОЇ ДІЯЛЬНОСТІ}

\begin{tabular}{|c|c|c|c|c|c|}
\hline \multirow{2}{*}{$\begin{array}{c}\text { № } \\
\text { показника }\end{array}$} & \multirow{2}{*}{ Уміння, знання, якості та ін. } & \multicolumn{3}{|c|}{ Групи НПП } & \multirow{2}{*}{$\begin{array}{l}\text { єндереС } \\
\text { яннечанз }\end{array}$} \\
\hline & & I & II & III & \\
\hline 1 & 2 & 3 & 4 & 5 & 6 \\
\hline 1 & $\begin{array}{l}\text { знання про особливості самовираження } \\
\text { самореалізації, ї форми та способи }\end{array}$ & 3,2 & 4,1 & 5,5 & 4,3 \\
\hline
\end{tabular}


Збірник наукових праць «Педагогіка та психологія». - Харків, 2020. - Вип. 63.

\begin{tabular}{|c|c|c|c|c|c|}
\hline 2 & $\begin{array}{l}\text { знання методології іміджотворчої діяльності, } \\
\text { розуміння її основних принципів, механізмів }\end{array}$ & 2,7 & 2,9 & 3,2 & 2,9 \\
\hline 3 & $\begin{array}{l}\text { знання ефективних методів, засобів створення і } \\
\text { корекції професійного іміджу }\end{array}$ & 5,1 & 7,2 & 5,2 & 5,8 \\
\hline 4 & $\begin{array}{lcc}\text { володіння } & \text { базовими } & \text { технологіями та } \\
\text { спеціальними } & \text { техніками } & \text { іміджотворчої } \\
\text { діяльності } & & \\
\end{array}$ & 2,5 & 2,1 & 2,7 & 2,4 \\
\hline 5 & $\begin{array}{l}\text { володіння тактиками } \\
\text { самопрезентації, самореалізації, самовираження }\end{array}$ & 6,3 & 6,2 & 6,7 & 6,4 \\
\hline 6 & $\begin{array}{l}\text { уміння, пов'язані з підтриманням позитивного } \\
\text { професійного іміджу в повсякденному житті }\end{array}$ & 5,4 & 6,2 & 5,3 & 5,6 \\
\hline 7 & $\begin{array}{l}\text { здатність критично аналізувати } \\
\text { результативність власної педагогічної діяльності }\end{array}$ & 6,7 & 7,2 & 4,3 & 6,1 \\
\hline 8 & рольова компетентність & 5,6 & 5,5 & 5,4 & 5,5 \\
\hline 9 & емоційна стабільність та стресостійкість & 2,7 & 2,4 & 2,4 & 2,5 \\
\hline 10 & харизма & 8,2 & 7,9 & 3,8 & 6,6 \\
\hline 11 & здатність до креативності & 6,7 & 6,4 & 8,5 & 7,2 \\
\hline 12 & естетична вихованість & 8,7 & 8,9 & 3,5 & 7 \\
\hline & Середнс значення & 5,3 & 5,6 & 4,7 & \\
\hline
\end{tabular}

Згідно з відповідями респондентів, ті характеристики, що пов'язані із креативністю, самопрезентацією та самовираженням, краще сформовані в молодих викладачів. Зокрема, викладачі III групи переконані, що вони характеризуються високим рівнем креативності (середній бал за цим показником дорівнює 8,5), тоді як у I і II групах середній бал за показником «здатність до креативності» - 6,7 та 6,4 відповідно. Природно, молоді педагоги переважають старших колег у володінні тактиками i стратегіями самопрезентації, самореалізації, самовираження (середній бал респондентів групи становить 6,7); тоді як у I та II групах - 6,3 і 6,2.

Натомість за такими показниками, як «харизма» та «естетична вихованість» переважають більш досвідчені викладачі. Наприклад, середній бал респондентів I групи більш, як на 4 бали, перевищує бал III групи за показником «харизма». Найбільшим ступенем естетичної вихованості, за результатами самооцінювання, характеризуються респонденти зі стажем педагогічної діяльності від 5 до 15 років (середній показник 8,9), що має незначну перевагу над I групою (середній показник 8,7), проте значно перевищує середній бал молодих викладачів (на 5,4 бали).

На жаль, викладачі вказали на досить низький рівень їх підготовленості до іміджотворчої діяльності. Зокрема, середня оцінка за показником «володіння базовими технологіями та спеціальними техніками іміджотворчої діяльності» в I групі становить 2,5 у II та III групі 2,1 та 2,7 відповідно. Отримані дані візуалізовано на рис. 1 .

Результати самооцінювання засвідчують фрагментарність знань респондентів про імідж як феномен, недостатне володіння механізмами іміджетворення, наявність утруднень у формуванні власного професійного іміджу, що свідчить про недостатню готовність більшості науково-педагогічних працівників до іміджетворення. На думку опитаних, усунути означені недоліки 
можливо через ознайомлення 3 теоретичними та методологічними засадами педагогічної іміджелогії, організації практикумів, тренінгів, семінарів, присвячених проблемам іміджетворення, набуття досвіду іміджетворення.

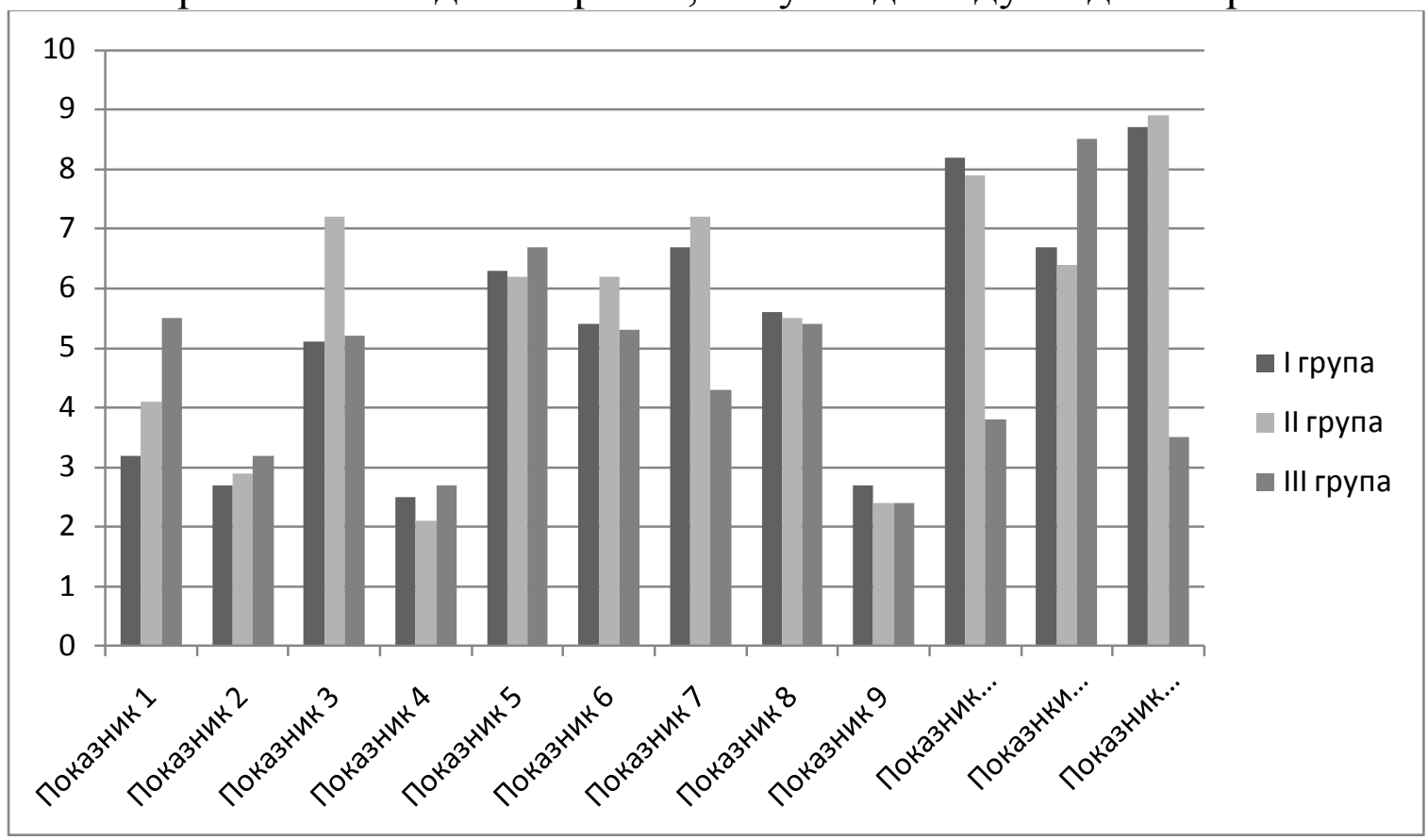

Рис. 1. Гістограма результатів самооцінювання викладачами здатності до іміджотворчої діяльності

Показники:

1 - знання про особливості самовираження та самореалізації, їх форми та способи

2 - знання методології іміджотворчої діяльності, розуміння ії основних принципів, механізмів

3 - знання ефективних методів, засобів створення і корекції професійного іміджу

4 - володіння базовими технологіями та спеціальними техніками іміджотворчої діяльності

5 - володіння тактиками і стратегіями самопрезентації, самореалізації, самовираження

6 - уміння, пов'язані з підтриманням позитивного професійного іміджу в повсякденному житті

7 - здатність критично аналізувати результативність власної педагогічної діяльності

8 - рольова компетентність

9 - емоційна стабільність та стресостійкість

10 - харизма

11 - здатність до креативності

12 - естетична вихованість

Висновки $з$ дослідження. Таким чином, розвідувальне дослідження засвідчило, що становлення професійного іміджу в освітньому процесі педагогічних закладів вищої освіти багато в чому протікає стихійно, відсутня єдина цілісна система його формування, надто обмеженим $є$ застосування в освітньому процесі ЗВО іміджевих технологій, переорієнтація складників нинішньої педагогічної системи на засади сучасних наукових концепцій $є$ вкрай повільною.

Це дало підстави для висновку щодо необхідності розроблення та впровадженні в освітній процес педагогічних закладів вищої освіти такої педагогічної системи цілеспрямованого формування професійного іміджу майбутніх учителів іноземних мов, що сприятиме підвищенню рівня сформованості професійного іміджу майбутніх учителів іноземних мов, уможливить їх успішне презентування себе як професіоналів у педагогічному й інших середовищах, a отже забезпечить соціальний успіх i 
конкурентноспроможність у сфері освітніх послуг.

Перспективи подальших розвідок. Це питання потребує переосмислення існуючого досвіду професійної підготовки таких фахівців і передбачає модернізацію структури та змісту навчання, адаптованість та уніфікацію освітніх програм, диференціацію та індивідуалізацію траєкторій навчання здобувачів освіти, а також належну підготовку науково-педагогічних працівників, залучених до освітнього процесу, до реалізації ідей іміджології, у чому вбачаємо перспективи подальших досліджень.

\section{Лimepamypa}

1. Ткаченко Н.M., Ткаченко I.O. До проблеми визначення поняття «професійний імідж». Colloquium-journal. 2019. № 21 (45). Warszawa, Poland. C. $58-60$.

2. Освітня програма «Англійська мова та література в закладах освіти». Харків. 2019. URL: http://smc.hnpu.edu.ua/files/Profili_OP/Angliuska_mova_i_ literatyra_v_zakladah_osvitu_bakalavr.pdf

3. Освітньо-професійна програма «Середня освіта (Англійська мова та література)» першого (бакалаврського) рівня вищої освіти за спеціальністю 014 Середня освіта (Мова i література (англійська)) галузі знань 01 Освіта/педагогіка. Тернопіль. 2017.2 UR1: http://tnpu.edu.ua/about/public_inform/akredytatsiia\%20ta\%20 litsenzuvannia/014_Serednja_osvita_English_bakalavr.pdf

4. Освітньо-професійна програма «Середня освіта (англійська та німецька мови) першого рівня вищої освіти за спеціальністю 014 Середня освіта (Мова i література (англійська)). Суми, 2016. URL: https://sspu.edu.ua/media/ attachments/2020/02/20/opp-bakalavr-anglnim2.pdf

5. Освітньо-професійна програма підготовки здобувачів освіти першого (бакалаврського) рівня вищої освіти галузі знань 01 Освіта/педагогіка спеціальності 014 Середня освіта (Мова і література (англійська)). Кривий ріг. 2016.

9JZwA2vl_VTe3Zge6pWX2V5HhC4Zx/view

6. Освітньо-професійна програма «014.02 Середня освіта. Мова та література (англійська)». Полтава. 2016. URL: http://pnpu.edu.ua/wpcontent/uploads/2020/03/2.-014.02-serednya-osvita-mova-i-literatura-anglijskabak.pdf

7. Освітньо-професійна програма «Середня освіта (Мова і література (англійська))» першого (бакалаврського) рівня вищої освіти за спеціальністю 014 Середня освіта Предметною спеціальністю 014 Середня освіта (Мова і література (Англійська)) галузі знань 01 Освіта/Педагогіка. Глухів. 2016. URL: http://nni.gnpu.edu.ua/images/OP/OP_eng_bak.pdf

8. Про затвердження Національної рамки кваліфікацій : постанова КМУ від 23 листопада 2011 р. № 1341. URL: https://zakon.rada.gov.ua/laws/show/13412011-\%D0\%BF/paran12\#n12

9. Про затвердження переліку галузей знань і спеціальностей, за якими здійснюється підготовка здобувачів вищої освіти» : постанова КМУ від 29 
квітня 2015 p. № 266. URL: https://zakon.rada.gov.ua/laws/show/ru/266-2015$\% \mathrm{D} 0 \% \mathrm{BF}$

10. Про затвердження Переліку предметних спеціальностей спеціальності 014 «Середня освіта (за предметними спеціальностями)», за якими здійснюється формування і розміщення державного замовлення та поєднання спеціальностей (предметних спеціальностей) в системі підготовки педагогічних кадрів : наказ MOH від 12 травня 2016 № $506 . \quad$ URL: https://zakon.rada.gov.ua/laws/show/z0798-16\#Text

\section{References}

1. Tkachenko, N. M., Tkachenko, I. O. (2019).To the problem of defining of the notion «professional image». Colloquium-journal. № 21 (45). Warszawa, Poland. C. 58-60. (in Ukrainian).

2. Educational program "English language and literature in educational institutions". Kharkiv. 2019. Retrieved from: http://smc.hnpu.edu.ua/files/Profili_OP /Angliuska_mova_i_literatyra_v_zakladah_osvitu_bakalavr.pdf (in Ukrainian).

3. Educational and professional program "Secondary education (English language and literature)" of the first (bachelor's) level of higher education in the specialty 014 Secondary education (Language and literature (English)) in the field of knowledge 01 Education/pedagogy. Ternopil. 2017. Retrieved from: http://tnpu.edu.ua/about/public_inform/akredytatsiia\%20ta\%20litsenzuvannia/014_Se rednja_osvita_English_bakalavr.pdf (in Ukrainian).

4. Educational and professional program "Secondary education (English and German)" of the first level of higher education in the specialty 014 Secondary education (Language and Literature (English)). Sumy, 2016. Retrieved from: https://sspu.edu.ua/media/ attachments/2020/02/20/opp-bakalavr-anglnim2.pdf (in Ukrainian).

5. Educational and professional program of training specialists for education of the first (bachelor's) level of higher education in the field of knowledge 01 Education / pedagogy specialty 014 Secondary education (Language and Literature (English)). Kryvyi Rih. 2016. Retrieved from: https://drive.google.com/file/d/1qx-9JZwA2vl_VTe3Zge6pWX2V5HhC4Zx/view (in Ukrainian).

6. Educational and professional program "014.02 Secondary education. Language and Literature (English)". Poltava. 2016. Retrieved from: http://pnpu.edu.ua/wp-content/uploads/2020/03/2.-014.02-serednya-osvita-mova-iliteratura-anglijska-bak.pdf (in Ukrainian).

7. Educational-professional program "Secondary education (Language and Literature (English))" of the first (bachelor's) level of higher education in specialty 014 Secondary education. Subject specialty 014 Secondary education (Language and Literature (English)) in the field of knowledge 01 Education / Pedagogy. Hlukhiv. 2016. Retrieved from: http://nni.gnpu.edu.ua/images/OP/OP_eng_bak.pdf (in Ukrainian).

8. The Cabinet of Ministers of Ukraine (2011). On approval of the National Qualifications Framework: Resolution. Retrieved from: 
https://zakon.rada.gov.ua/laws/show/1341-2011-\%D0\%BF/paran12\#n12

Ukrainian).

9. The Cabinet of Ministers of Ukraine (2015). On approval of the list of branches of knowledge and specialties of training specialists in higher education : Resolution. Retrieved from: https://zakon.rada.gov.ua/laws/show/ru/266-2015$\% \mathrm{D} 0 \% \mathrm{BF}$ (in Ukrainian).

10. The Ministry of Education of Ukraine (2016). On approval of the list of subject specialties of the specialty 014 Secondary education (on subject specialties) which is the bases for forming the state order and combining of specialties (subject specialties) in the system of pedagogical staff training : order. Retrieved from: https://zakon.rada.gov.ua/laws/show/z0798-16\#Text (in Ukrainian). 